I Universidade Federal do Rio de Janeiro (UFRJ), Departamento de

Sociologia, Rio de Janeiro, RJ, Brasil

glauciavboas@gmail.com

https://orcid.org/oooo-00oI-5357-740X

Glaucia Villas Bôas'

\title{
MAX WEBER SOB A LUPA. OBITUÁRIO DE GUENTHER ROTH
}

Há dez anos escrevi para Guenther Roth convidando-o para fazer parte do Conselho Editorial de Sociologia \& Antropologia. Ele me respondeu prontamente. Perguntou como poderia contribuir para o periódico brasileiro uma vez que não tinha muito tempo para se dedicar ao conselho e não lia português. A resposta não era usual, mas acabei convencendo o professor Roth a aceitar o convite. Ele foi um dos membros do conselho que mais ajudou nos primeiros anos de vida da revista do PPGSA, enviando-me contatos de sociólogos alemães e norteamericanos, dirimindo dúvidas que eu tinha, dando-me informações de que eu precisava. Lia sempre os resumos em inglês dos números da revista que eu lhe enviava e fazia pequenos comentários. De sua própria autoria, S\&A publicou dois artigos: "Edgar Jaffé e Elsie Richthofen à luz de cartas recém-descobertas" (20I I) e "Angerona: fatos e ficções sobre a fazenda de café de Cornelio Souchay e Ursula Lambert em Cuba" (20I2).

Conheci o professor Roth em I997, pouco depois de sua aposentaria, quando ainda estava se desfazendo de sua sala na Universidade de Columbia. Fomos almoçar em um restaurante da Avenida Amsterdam e conversamos sobre as traduções e a recepção da obra de Max Weber. Em seguida ele me convidou a acompanhá-lo à sua sala e lá me presenteou com um exemplar da edição norte-americana de Economia e Sociedade, a primeira tradução completa do livro de Max Weber em inglês, que ele preparara com Claus Wittich e que fora publicada em I968. A introdução ao livro, escrita por Roth, revela com clareza e precisão as bases teórico-sociológicas, comparativas e históricas de Economia 
e Sociedade, ressaltando o valor do livro para o entendimento da modernidade em contraste com as teorias sistêmicas.

Guenther Roth nasceu em I93I em Wolfskehlen, na Alemanha. Estudou ciências socias na Universidade de Frankfurt com Theodor Adorno, Max Horheimer e Friedrich Pollock. Em I952, emigrou para os Estados Unidos e terminou seus estudos na Universidade de Berkeley, onde foi assistente de Reinhardt Bendix. A boa recepcão de sua tese de doutorado, The social democrats in imperial German. A study of working class isolation and national integration, defendida em I963, favoreceu a continuidade de sua trajetória acadêmica em solo norte-americano. Ao longo dos anos, Roth dedicou-se à pesquisa da obra de Max Weber, tornando-se um especialista renomado. Numa primeira linha de estudos, retomou a sociologia histórica de Max Weber para refletir sobre problemas contemporâneos à luz de conceitos como dominação política, carisma e patrimonialismo; numa segunda linha, voltou-se para a análise do contexto político e intelectual da obra de Weber e traçou a recepção do pensamento do autor em diferentes círculos intelectuais. Em 200I, publicou, na Alemanha, Max Webers deutsch-englische Familiengeschichte I800-I950, um estudo minucioso da família burguesa de Weber e seu percurso do cosmopolitismo ao nacionalismo.

Entre tantos livros e artigos de Guenther Roth, sempre me chamou a atenção a Introdução que escreveu para Max Weber. Uma biografia, de Marianne Weber. De maneira delicada e firme ele recupera a importância de Marianne Weber e de outras mulheres estudiosas, em sua maioria feministas, que pela primeira vez participaram ativamente com os homens da vida intelectual e acadêmica na Alemanha, trazendo à luz suas conquistas e seus dissabores.

No obituário que escreveu para o Frankfurter Allgemeine Zeitung, Friedrich Wilhelm Graf considera que o sociólogo foi um construtor de pontes entre jovens pesquisadores alemães e o sistema acadêmico norte-americano, levando aqueles que recebia em Nova York invariavelmente para visitar um dos bons museus da cidade. Graf esqueceu que não eram somente os jovens alemães que ele levava para passear pela cidade. Muitos jovens estudiosos brasileiros e latinoamericanos também o procuravam e se sentiram por ele acolhidos. O convite era um dos hábitos que o bom anfitrião cultivava.

Guenther Roth faleceu no dia 8 de maio, na sua casa em Nova York, depois de receber a visita de um jovem amigo alemão e de contemplar o rio Hudson, de que tanto gostava. 